\title{
Human Blood-Brain Barrier Receptors for Alzheimer's Amyloid- $\beta$ 1-40 Asymmetrical Binding, Endocytosis, and Transcytosis at the Apical Side of Brain Microvascular Endothelial Cell Monolayer
}

\author{
Jasmina B. Mackic, ${ }^{\star}$ Monique Stins, ${ }^{\ddagger}$ J. Gordon McComb,§ Miguel Calero, \\ David Stern," Ann Marie Schmidt," Blas Frangione," and Berislav V. Zlokovic $\S^{\circledR}$ \\ *Department of Neurological Surgery, ${ }^{\ddagger}$ Division of Infectious Diseases, and ${ }^{\S}$ Division of Neurosurgery Children’s Hospital, \\ USC School of Medicine, Los Angeles, California 90033; "Department of Pathology, New York University Medical Center, New York, \\ New York 10016; and "I Departments of Pathology, Physiology, and Surgery, College of Physicians and Surgeons of Columbia University, \\ New York, New York 10032
}

\begin{abstract}
A soluble monomeric form of Alzheimer's amyloid- $\beta$ (1-40) peptide $\left(\mathrm{sA} \beta_{1-40}\right)$ is present in the circulation and could contribute to neurotoxicity if it crosses the brain capillary endothelium, which comprises the blood-brain barrier (BBB) in vivo. This study characterizes endothelial binding and transcytosis of a synthetic peptide homologous to human $\mathrm{sA} \beta_{1-40}$ using an in vitro model of human BBB. ${ }^{125} \mathrm{I}-\mathrm{sA} \beta_{1-40}$ binding to the brain microvascular endothelial cell monolayer was time dependent, polarized to the apical side, and saturable with high- and low-affinity dissociation constants of $7.8 \pm 1.2$ and $52.8 \pm 6.2 \mathrm{nM}$, respectively. Binding of ${ }^{125} \mathrm{I}-\mathrm{sA} \beta_{1-40}$ was inhibited by anti-RAGE (receptor for advanced glycation end products) antibody (63\%) and by acetylated low density lipoproteins (33\%). Consistent with these data, transfected cultured cells overexpressing RAGE or macrophage scavenger receptor (SR), type $A$, displayed binding and internalization of ${ }^{125} \mathrm{I}-\mathrm{sA} \beta_{1-40}$. The internalized peptide remains intact $>94 \%$. Transcytosis of ${ }^{125} \mathrm{I}-\mathrm{sA} \beta_{1-40}$ was time and temperature dependent, asymmetrical from the apical to basolateral side, saturable with a Michaelis constant of $45 \pm 9 \mathrm{nM}$, and partially sensitive to RAGE blockade $(36 \%)$ but not to SR blockade. We conclude that RAGE and SR mediate binding of $\mathrm{sA} \beta_{1-40}$ at the apical side of human BBB, and that RAGE is also involved in sA $\beta_{1-40}$ transcytosis. (J. Clin. Invest. 1998. 102:734-743.) Key words: A $\beta$-peptide - cerebrovascular • transporter • central nervous system $\bullet$ amyloidosis
\end{abstract}

\section{Introduction}

Amyloid $\beta(A \beta),{ }^{1}$ a heterogenous, $39-43$ amino acid peptide, is the main constituent of the senile plaques and cerebrovascular deposits, the primary lesions in Alzheimer's disease (AD) (1,

Preliminary findings were reported to the Society of Neuroscience, 25-30 October 1997, in New Orleans, LA, and have appeared in abstract form (1997. Soc. Neurosci. Abs. 23:2235).

Address correspondence to Berislav V. Zlokovic, M.D., Ph.D., USC School of Medicine, 2025 Zonal Avenue, RMR 506, Los Angeles, CA 90033. Phone: 213-342-2698; FAX: 213-342-3270; E-mail: zlokovic@hsc.usc.edu

Received for publication 16 October 1997 and accepted in revised form 28 May 1998.

J. Clin. Invest.

(C) The American Society for Clinical Investigation, Inc. 0021-9738/98/08/0734/10 \$2.00

Volume 102, Number 4, August 1998, 734-743

http://www.jci.org
2). $A \beta$ is considered to be central to the pathology of AD because it may be neurotoxic - directly by inducing oxidant stress and indirectly by activating microglia (3-5). It has been suggested that the presence of pathological "chaperone" proteins in brain and/or other predisposing factors is critical for the cytotoxic effects of $A \beta$ (1). A soluble monomeric form of $A \beta$ $(\mathrm{sA} \beta)$ is normally produced by different types of cells (6) and is present in the circulation and cerebrospinal fluid (CSF) $(7,8)$ and in brain parenchyma (9). The 40-amino-acid peptide $A \beta_{1-40}$ accounts for approximately $90 \%$ of $\mathrm{A} \beta$ released from cells in culture (6) and is the predominant form of cerebrovascular amyloid $(10,11)$. The longer 42 -residue peptide, $A \beta_{1-42}$, accounts for only $10 \%$ of secreted $\mathrm{A} \beta$ but is the major constituent of senile plaques (12). Recent quantitative analysis has demonstrated that $31 \%$ of all plaques contain $A \beta_{1-40}$, while $60 \%$ are labeled with $A \beta_{1-42}$ (13).

The origin of the $A \beta$ deposited in cerebral vasculature and brain is uncertain. According to the "neuronal theory" $A \beta$ is produced locally in brain. In contrast, the "vascular theory" proposes that $A \beta$ originates from the circulation, and that circulating $\mathrm{sA} \beta$ could contribute to neurotoxicity if it crosses the brain capillary endothelium, which comprises the blood-brain barrier (BBB) in vivo (14). Transport of several peptides and proteins through the brain capillary endothelium is possible via receptor-mediated transcytosis (15-19). It has been suggested that specific receptor mediates BBB transport of circulating $\mathrm{sA} \beta_{1-40}$ in rodents and nonhuman primates $(14,20-22)$. However, direct transport of $\mathrm{sA} \beta_{1-40}$ across the $\mathrm{BBB}$ in humans has not been studied, and it is not known whether specific binding and/or transport mechanisms for $\mathrm{sA} \beta_{1-40}$ exist at human brain microvascular endothelial cells (HBMECs). In addition, previously used in vivo techniques $(14,21-23)$ lack the resolution to compare peptide binding and transport at the apical versus basolateral side of brain endothelium. We hypothesized that specific receptor(s) for $\mathrm{sA} \beta_{1-40}$ are present in human brain capillaries, and that their endothelial cellular distribution may favor asymmetrical binding and transport of peptide at the BBB. Thus, apical-to-basolateral transport may allow circulating peptide to enter the brain and vessel wall

1. Abbreviations used in this paper: AcLDL, acetylated low density lipoproteins; $K_{\mathrm{m}}$, affinity (Michaelis) constant; $\mathrm{A} \beta$, amyloid $\beta$ peptide; $\mathrm{AD}$, Alzheimer's disease; $B_{\max }$, binding maximum; BBB, blood-brain barrier; CSF, cerebrospinal fluid; $K_{\mathrm{d}}$, dissociation constant; gp330, glycoprotein 330; HBMEC, human brain microvascular endothelial cell; HPLC, high pressure liquid chromatography; PS product, permeability surface area product; PAO, phenylarsine oxide; RAGE, receptor for advanced glycation end products; SR, scavenger receptor. 
which could be associated with its cytotoxic effects. In contrast, basolateral-to-apical transport may favor clearance of $\mathrm{sA} \beta$ from brain into blood that may ultimately decrease its tissue levels. An in vitro model of human $\operatorname{BBB}(24,25)$ was used to test the above hypothesis and to characterize apical versus basolateral HBMEC binding, endocytosis, and transcytosis of a synthetic peptide homologous to human $\mathrm{sA} \beta_{1-40}$. The roles of recently described receptors for free $A \beta$, including the receptor for advanced glycation end products (RAGE) (4) and scavenger receptor (SR) (5), were studied.

\section{Methods}

Chemicals. Peptide DAEFRHDSGYEVHHQKLVFFAEDVGSNKGAIIGLMVGGVV (sA $\beta_{1-40}$ ), homologous to residues $672-711$ of $\beta$-precursor amyloid protein (1-770) was custom synthesized at the W.M. Keck Facility at Yale University using solid-phase $N$-tert-butyloxycarbonyl chemistry. Peptide was purified by reverse-phase high pressure liquid chromatography (HPLC) using a C18 column (Vydac, Hesperia, CA) and a linear gradient of $0-80 \%$ acetonitrile in $0.05 \%$ trifluoroacetic acid (TFA). The final product was lyophilized and characterized by analytical reverse phase HPLC, amino acid analysis, and laser desorption spectrometry. The secondary structure of $\mathrm{sA} \beta_{1-40}$ was determined by circular dichroism and consisted of $0 \% \alpha$-helix, $27.7 \% \beta$-sheet, $0.6 \% \beta$-turn; and $71.7 \%$ random coil. The reverse synthetic peptide VVGGVMLGIIAGKNSGVDEAFFVLKQHHVEYGSDHRFEAD $\left(\mathrm{A} \beta_{40-1}\right)$ was purchased from Sigma Chemical Co. (St. Louis, MO). sA $\beta_{1-40}$ was labeled with $\mathrm{Na}\left[{ }^{125} \mathrm{I}\right](13.7 \mathrm{mCi} / \mu \mathrm{g}$; Amersham Corp., Arlington Heights, IL) using Iodobeds (Pierce Chemical Co., Rockford, IL) following the manufacturer's instructions. To revert the potential sA $\beta_{1-40}$ oxidation at Met35 due to the radioiodination procedure, the peptide was subjected to reduction with $0.1 \mathrm{M}$ dithiothreitol for $6 \mathrm{~h}$ before purification. Labeled peptides were separated from free iodine and oxidation derivatives by reverse-phase HPLC using a 5- $\mu \mathrm{m} \mathrm{C4}$ narrow bore column (Vydac) and a 45-min linear gradient from $0-70 \%$ acetonitrile. Protein elution was monitored by absorbance at $280 \mathrm{~nm}$ and radioactivity evaluated in a gamma counter (Beckman Instruments, Fullerton, CA). The resulting specific activity of $\left[{ }^{125} \mathrm{I}\right] \mathrm{sA} \beta_{1-40}$ was $7.6 \mu \mathrm{Ci} / \mu \mathrm{g}$, and $>97 \%$ TCA precipitable. Changes in the secondary structure due to the radioiodination procedure were evaluated by circular dichroism. Spectra in the far ultraviolet range $(260-190 \mathrm{~nm})$ were recorded at $241 \mathrm{C}$ with a spectropolarimeter (model J-720; Jasco Inc., Easton, MD) using a cell path of $0.1 \mathrm{~cm}$ at a peptide concentration of $0.15 \mathrm{mg} / \mathrm{ml}$ in $20 \mathrm{mM}$ Tris, $\mathrm{pH}$ 7.4.

Isolation of human brain capillaries. Human brain capillaries were isolated from small fragments of cerebral cortex obtained from surgical resections from three adults with seizure disorder, as we recently described (24). Portions with no pathologic lesions were used. Briefly, brain specimens devoid of large blood vessels were homogenized in DMEM containing 2\% fetal bovine serum (FBS) using a Dounce homogenizer (VWR, San Diego, CA). The homogenate was centrifuged in $15 \%$ dextran in DMEM for $10 \mathrm{~min}$ at $10,000 \mathrm{~g}$. The pellets containing crude microvessels were further digested in a solution containing $1 \mathrm{mg} / \mathrm{ml}$ collagenase/dispase in DMEM-S for $1 \mathrm{~h}$ at $37^{\circ} \mathrm{C}$. Microvascular capillaries were isolated by absorption to a column of glass beads and washing off the beads. Cell viability was $>95 \%$ as judged by a trypan blue exclusion test.

Cultures and characterization of HBMECs. The human brain microvessels were plated on rat-tail collagen-coated dishes or glass coverslips and cultured in RPMI 1640-based medium with growth factors (24), FBS, NuSerum, endothelial cell growth supplement, heparin $(5 \mathrm{U} / \mathrm{ml})$, L-glutamine $(2 \mathrm{mM})$, sodium pyruvate $(1 \mathrm{mM})$, nonessential amino acids, vitamins, penicillin, and streptomycin (100 $\mathrm{U} / \mathrm{ml}$ ) (24). Cultures were incubated at $37^{\circ} \mathrm{C}$ in a humid atmosphere of $5 \% \mathrm{CO}_{2}$. The resulting HBMECs were positive for factor VIII- related antigen, carbonic anhydrase IV, Ulex Europeus Agglutinin I, and took up acetylated low density lipoprotein (AcLDL, ligand for endothelial SR [5]) demonstrating their endothelial origin. HBMECs also expressed $\gamma$-glutamyl transpeptidase, indicating their brain origin. Detailed procedures regarding characterization of HBMECs were as we previously reported (24).

In a separate set of experiments, cytospin slides of HBMECs were prepared with a cytospin centrifuge (Shandon Lipshaw Corp., Pittsburgh, PA), and slides were rehydrated and stained with polyclonal rabbit antihuman anti-RAGE antibodies (4). Secondary peroxidase-labeled antibodies and development with diaminobenzidine were used. Sections were lightly stained with hematoxylin. Fluorescent-labeled DiI-AcLDL was used to demonstrate the presence of SR (5). HBMECs were incubated with DiI-AcLDL $(10 \mu \mathrm{g} / \mathrm{ml})$ for $4 \mathrm{~h}$ at $37^{\circ} \mathrm{C}$, fixed with $2.5 \%$ glutaraldehyde in phosphate-buffered saline (PBS), and viewed. Pictures were taken with a fluorescence microscope (Nikon, Tokyo, Japan) as described (24).

In vitro model of the $B B B$. Using the HBMECs, the $\mathrm{BBB}$ in vitro model was constructed in inserts with collagen-fibronectin-coated polycarbonate in Transwell membrane filters (Costar Corp., Cambridge, MA) as we reported (25). A single monolayer of HBMECs was produced by placing $200 \mu \mathrm{l}$ of cell suspension containing $5 \times 10^{5}$ cells in the upper chamber of a 24-well tissue culture insert and 1,000 $\mu l$ in the lower chamber. Analysis of the BBB by transmission electron microscopy (TEM) in 5-day-old primary cultures revealed flat monolayers of endothelial cells covering the porous membrane completely. The apical surface of endothelial cells had neither microvilli nor cytoplasmic processes. The cytoplasm of HBMECs contained elongated nuclei, free ribosomes, few mitochondria, and endoplasmic reticulum. Typical rod-shaped Weibel Palade bodies were observed with a dark striated appearance. Bundles of intermediate filaments were located under the basolateral cytoplasmic membrane, and microtubules were evenly distributed in the HBMEC cytoplasm. Occasionally two or three HBMECs were overlaid on one another. Formation of gap and tight junctions were found between the thin cytoplasmic processes of HBMECs. As we reported, the presence of astrocytes did not positively affect the tightness of the HBMEC monolayer in this model (26), and therefore they were not used in the present studies.

$s A \beta_{1-40}$ binding to HBMEC monolayers. The HBMECs were preincubated for $1 \mathrm{~h}$ in RPMI culture medium with $10 \%$ FBS. The tracer solution containing $\left[{ }^{125} \mathrm{I}\right] \mathrm{sA} \beta_{1-40}(0.5 \mathrm{nM})$ and $\left[{ }^{14} \mathrm{C}\right]$ inulin $(10 \mathrm{nM})$ was added to either the apical (upper) or basolateral (lower) chamber for different periods of time within $60 \mathrm{~min}$ at either $37^{\circ} \mathrm{C}$ or $4^{\circ} \mathrm{C}$. The effects of internalization (endocytosis) and metabolism of ligand by HBMECs were studied at $37^{\circ} \mathrm{C}$. The inhibition of cell surface binding for Scatchard analysis was carried out at $4^{\circ} \mathrm{C}$, and the tracer solution was supplemented with various concentrations of unlabeled sA $\beta_{1-40}$ $(0.5-150 \mathrm{nM})$ or $150 \mathrm{nM} \mathrm{A} \beta_{40-1}$. To determine intracellular and surface-bound $s A \beta_{1-40}$, HBMEC monolayers were first washed three times in Hank's balanced salt solution to remove unbound tracer, and then exposed to $1 \mathrm{ml}$ of acid wash solution $(0.2 \mathrm{M}$ acetic acid and $0.5 \mathrm{M}$ $\mathrm{NaCl}, \mathrm{pH} 3.0$, for $6 \mathrm{~min}$ at $\left.4^{\circ} \mathrm{C}[27]\right)$. To determine which of the $\mathrm{sA} \beta_{1-40}$ receptors participate in binding, the HBMEC monolayers were treated for $30 \mathrm{~min}$ at $4^{\circ} \mathrm{C}$ before and during [ $\left.{ }^{125} \mathrm{I}\right] \mathrm{sA} \beta_{1-40}$ incubation with different concentrations of anti-RAGE antibodies (4) or AcLDL, a ligand for SR (5). To block the internalization of $\mathrm{sA} \beta_{1-40}$, HBMEC monolayers were treated for $30 \mathrm{~min}$ at $37^{\circ} \mathrm{C}$ before and during [ $\left.{ }^{125} \mathrm{I}\right] \mathrm{sA} \beta_{1-40}$ incubation with endocytic inhibitor, phenylarsine oxide (PAO) at $20 \mu \mathrm{M}(28-31)$. Although the exact molecular mechanism for the inhibitory effect of PAO on endocytosis is not known, it has been suggested that this trivalent arsenical forms a stable ring with vicinal sulfhydryl groups, affects phosphoinositide metabolism, and at higher concentrations reduces cellular energy stores, but at a concentration used to inhibit endocytosis its other cellular actions are minimized $(28,29)$. PAO inhibits internalization of several peptide ligands (e.g., epidermal growth factor, insulin) (29), and at the BBB receptor-mediated endocytosis of insulin (30) as well as endothelial endocytosis of dynorphins (31). 
The HBMECs were detached from the membrane insert using $0.1 \%$ EDTA in Hank's solution. For degradation studies, the HBMECs were incubated with $\left[{ }^{125} \mathrm{I}\right] \mathrm{sA} \beta_{1-40}(3.5 \mathrm{nM})$ within $30 \mathrm{~min}$ at $37^{\circ} \mathrm{C}$. Aliquots of the assay buffer and endothelial cell homogenates were prepared for analysis of total and TCA (12\%)-precipitable [ $\left.{ }^{125} \mathrm{I}\right]$ radioactivities to determine the fraction of $\left[{ }^{125} \mathrm{I}\right] \mathrm{SA} \beta_{1-40}$ that was not degraded. Uptake and metabolism of $\mathrm{sA} \beta_{1-40}$ by HBMECs were also studied in several assay buffer and HBMEC samples with HPLC to corroborate the results of TCA precipitation analysis. Prior to extraction and HPLC fractionation, the HBMECs were exposed to acid wash solution ( $0.2 \mathrm{M}$ acetic acid and $0.5 \mathrm{M} \mathrm{NaCl}$ for $6 \mathrm{~min})$ to remove surface-bound $\mathrm{sA} \beta_{1-40}$. HBMEC samples were then prepared by hypotonic lysis as reported (32). Briefly, HBMECs were homogenized in water containing protease inhibitors $(0.5 \mathrm{mM}$ phenylmethylsulfonyl fluoride, $1 \mu \mathrm{g} / \mathrm{ml}$ leupeptin, and $1 \mathrm{mM} p$-amino-benzamidine) and centrifuged at $100,000 \mathrm{~g}$ for $1 \mathrm{~h}$ at $4^{\circ} \mathrm{C}$. The supernatant was then lyophilized. The resulting material was dissolved in $0.1 \%$ TFA in water, $\mathrm{pH} 2.1$, before injection onto the HPLC column. The aliquots of assay buffer samples from upper and lower chamber were diluted in $0.1 \%$ TFA in water, $\mathrm{pH} 2.1$, before injection onto the HPLC column. Separation was achieved using a $\mathrm{C} 4$ column (Vydac, The Separation Group) with a 30-min linear gradient of $25-83 \%$ acetonitrile in $0.1 \%$ TFA at a flow rate of $1 \mathrm{ml} / \mathrm{min}$. Under these conditions, the sA $\beta_{1-40}$ standard eluted at $15.5 \mathrm{~min}$. Column eluants were monitored at 214 $\mathrm{nm}$. The eluted fractions were collected and counted using a gamma counter (Beckman Instruments). Protein content of the BMEC monolayers was determined by the Lowry method (33).

All measurements were done in triplicate. $\left[{ }^{125} \mathrm{I}\right]$ and $\left[{ }^{14} \mathrm{C}\right]$ radioactivities were determined in a gamma counter (model 4000; Beckman Instruments) and a liquid scintillation spectrometer (model LS-7500; Beckman Instruments), respectively. Parameters governing the binding of $\left[{ }^{125} \mathrm{I}\right] \mathrm{sA} \beta_{1-40}$ to BMECs were estimated by nonlinear least squares regression using the software program SAAM II (University of Washington, Seattle, WA), with initial parameter estimates determined by Scatchard analysis (34).

$s A \beta_{1-40}$ transendothelial transport across HBMEC monolayers. These experiments were carried out at $37^{\circ} \mathrm{C}$. Samples $(0.2 \mathrm{ml})$ were removed from both the apical (upper) and basolateral (lower) chambers to determine the extent of tracer passage across the BMEC monolayer. To control for nonspecific ${ }^{125} \mathrm{I}$-sA $\beta_{1-40}$ leakage, ${ }^{14} \mathrm{C}$-inulin leakage across monolayers was determined simultaneously in all experiments. The amount of intact sA $\beta$ transcytosed across the HBMECs was expressed as the percent of the radioactivity dose of ${ }^{125} \mathrm{I}-\mathrm{sA} \beta_{1-40}$ transported from the apical to basolateral side and corrected for the nonspecific leakage as (16): ${ }^{125} \mathrm{I} \mathrm{cpm} \times$ TCA-precipitable radioactivity in sample $-\left[{ }^{125} \mathrm{I} \mathrm{cpm} \times\right.$ TCA-precipitable radioactivity in dose $\times$ $k \times\left({ }^{14} \mathrm{C} \mathrm{dpm}\right.$ in sample $/{ }^{14} \mathrm{C} \mathrm{dpm}$ in dose $\left.)\right]$, where sample and dose denote the radioactivities of intact $\mathrm{sA} \beta$ in the lower (basolateral) and upper (apical) chamber, respectively, when the radiolabeled peptide was added to the upper chamber; $k=(\text { molecular weight of inulin })^{1 / 2} /$ (molecular weight of $\left.\mathrm{sA} \beta_{1-40}\right)^{1 / 2}$ to correct for the nonspecific leakage and the differences in inulin and $\mathrm{sA} \beta_{1-40}$ diffusion across the coated membrane. When basolateral-to-apical transport of sA $\beta$ was studied, the same formula was applied, but in this case the dose represented the radioactivity of intact $\mathrm{sA} \beta$ added to the basolateral chamber, and the sample represented the radioactivity of $\mathrm{sA} \beta$ in the upper chamber. Since transendothelial basolateral-to-apical transport of sA $\beta$ corrected for nonspecific leakage was undetectable, the transport parameters described below were determined only for apical-tobasolateral transport. Degradation of $\mathrm{sA} \beta_{1-40}$ following transport across the HBMECs was studied in several assay buffer samples from the apical and basolateral chambers with HPLC (31) using the procedure as described above. The HPLC analysis was performed to corroborate the results of TCA precipitation analysis. The permeability-surface area $(P S)$ product for $\mathrm{sA} \beta_{1-40}$ in the apical-to-basolateral direction was calculated using the equation $P S=X /\left(A \times t \times C_{\mathrm{D}}\right)$ where $X$ and $C_{\mathrm{D}}$ are concentrations of ${ }^{125} \mathrm{I}-\mathrm{sA} \beta_{1-40}$ in lower and upper chamber, respectively, $t$ is the time of exposure, and $A$ is the surface area, as reported (16). The inhibition of ${ }^{125} \mathrm{I}-\mathrm{sA} \beta_{1-40}$ transport in apical-tobasolateral direction was studied in the presence of unlabeled $\mathrm{sA} \beta_{1-40}$ $(0.5-150 \mathrm{nM}), 150 \mathrm{nM} \mathrm{sA} \beta_{40-1}$ and different concentrations of antiRAGE antibody $(5-40 \mu \mathrm{g} / \mathrm{ml})$ and AcLDL $(50-800 \mu \mathrm{g} / \mathrm{ml})$. The transendothelial apical-to-basolateral influx, $J_{\text {in }}$, of ${ }^{125} \mathrm{I}-\mathrm{sA} \beta_{1-40}$ in the presence of various concentrations of unlabeled peptide in the upper chamber, $C$, was calculated as $(16,19): J_{\text {in }}=P S \times C \times q$, where $q$ is the amount of protein (in $\mathrm{mg}$ ) per number of cells in HBMEC monolayers occupying the surface area $A$ available for transendothelial transport. Kinetic transport Michaelis-Menten parameters, $K_{\mathrm{m}}$ (Michaelis affinity constant) and $V_{\max }$ (maximal transport capacity) for intact $\mathrm{sA} \beta_{1-40}$ were calculated with a nonlinear regression analysis using SAAM II program as reported (19).

Radioligand binding and internalization studies in transfected cultured cells overexpressing RAGE or macrophage SR type A. For the RAGE overexpression system, Chinese hamster ovary (CHO) cells were transiently transfected with pcDNA3/RAGE (human RAGE) using lipofectamine (GIBCO/BRL, Grand Island, NY). RAGE expression in these cells was characterized by immunoblotting and immunocytochemistry as described (35). For the SR overexpression system, Bowes cells stably transfected to overexpress the macrophage SR type A, characterized as previously described (36), were employed. In brief, cultures were grown to confluence $\left(\sim 10^{6}\right.$ cells/well), medium was aspirated, cells were washed with Hank's balanced salt solution over $10 \mathrm{~min}(5 \mathrm{~min} / \mathrm{wash})$ at room temperature, and then binding buffer (minimal essential medium containing fatty acid-free bovine serum albumin $0.1 \%$ ) was added $(50 \mu \mathrm{l} /$ well). For radioligand binding studies, cultures were briefly $(20 \mathrm{~min})$ pretreated with paraformaldehyde ( $2 \%$ ) after the washing procedure to prevent internalization of bound ligand as described previously (37). Wells were incubated with ${ }^{125} \mathrm{I}$-sA $\beta_{1-40}$ alone or in the presence of an 100 -fold molar excess of unlabeled sA $\beta_{1-40}$ for $120 \mathrm{~min}$ at $37^{\circ} \mathrm{C}$. This incubation time was required for apparent maximal binding at the lowest tracer concentrations. After the incubation period, wells were rapidly washed four times in ice-cold binding buffer over $30 \mathrm{~s}$ (this time period was sufficiently rapid to prevent significant dissociation of bound ligand [ $<5-10 \%]$ ). Cell-bound radioactivity was eluted by incubating wells for $5 \mathrm{~min}$ at $37^{\circ} \mathrm{C}$ with PBS containing heparin $(10 \mathrm{mg} / \mathrm{ml})$ or with saline containing NP-40 (1\%) for $5 \mathrm{~min}$ at $37^{\circ} \mathrm{C}$. Specific binding, the difference between total binding (that observed with ${ }^{125} \mathrm{I}-\mathrm{sA} \beta_{1-40}$ alone) and nonspecific binding (that observed with ${ }^{125} \mathrm{I}-\mathrm{sA} \beta_{1-40}$ in the presence of an 100 -fold excess of unlabeled $\mathrm{sA} \beta_{1-40}$ ) was analyzed by the method of Klotz and Hunston (37), using nonlinear least squares analysis (Enzfitter). Specific binding according to these methods was identical following elution with heparin or NP-40.

For internalization studies, similar methodology was employed, except cells were not exposed to paraformaldehyde. The experiment was also performed at $37^{\circ} \mathrm{C}$ for $1 \mathrm{~min}$. Following washing to remove unbound tracer, cultures were sequentially exposed to heparin-containing buffer (as above), to elute surface-bound radioactivity, and then NP-40, to elute cell-associated radioactivity not accessible to heparin (i.e., internalized ligand). For morphologic studies, cultures were incubated with nonradioactive $\mathrm{sA} \beta_{1-40}$ according to the same protocol described above for tracking internalized ligand. Then, cultures were fixed in paraformaldehyde $(2 \%)$ with/without NP-40 $(0.1 \%)$ and studied for localization of $A \beta$ by immunocytochemistry using anti- $\mathrm{A} \beta_{1-40}$ immunoglobulin $\mathrm{G}(\mathrm{IgG})$ as the primary antibody (QCB, Hopkinton, MA) and affinity purified fluorescein isothiocyanate-labeled goat anti-rabbit IgG as the secondary antibody (Sigma Chemical Co.).

\section{Results}

The analysis of HBMECs by TEM in 5-day-old primary cultures revealed a flat and continuous monolayer of cells bound by the tight junctions (Fig. $1 A$ ). At $37^{\circ} \mathrm{C}$, the specific binding of $\mathrm{sA} \beta_{1-40}$ was found only at the apical side and was absent 
from the basolateral side (Fig. $1 \mathrm{~B}$ ). The total binding of ${ }^{125} \mathrm{I}$ $\mathrm{sA} \beta_{1-40}(0.5 \mathrm{nM})$ to the apical cell surface was rapid and progressively increased within the first $5 \mathrm{~min}$. A steady-state level was reached between 5 and $60 \mathrm{~min}$. The majority of binding (75-80\%) was resistant to removal by acid wash, indicating incorporation into apical membrane or endocytosis at physiological temperature. The temperature dependence of $\mathrm{sA} \beta_{1-40}$ binding and internalization was evident (Fig. $1 C$ ). At $4^{\circ} \mathrm{C}$, the total binding at the apical side was significantly reduced, associated with a decrease in acid-resistant binding (i.e., intracellular binding). There was a minimal degree of metabolism or degradation of ${ }^{125} \mathrm{I}-\mathrm{sA} \beta_{1-40}$ by $\mathrm{HBMECs}$ at $37^{\circ} \mathrm{C}$ (Fig. $\left.1 \mathrm{D}\right)$; after $30 \mathrm{~min}$ and $60 \mathrm{~min}$ (data not shown) $>94 \%$ of peptide (corrected for the counts removed by an acid wash) remained intact in endothelial cells as confirmed by the HPLC analysis of HBMEC lysates following removal of cell surface-bound
${ }^{125} \mathrm{I}-\mathrm{sA} \beta_{1-40}$ by an acid wash. Similar results were obtained when trypsin:proteinase K:EDTA solution was used to remove cell surface-bound ligand (data not shown). Binding of ${ }^{125} \mathrm{I}-\mathrm{sA} \beta_{1-40}$ to the apical side was saturable in the presence of increasing concentrations of unlabeled $\mathrm{sA} \beta_{1-40}$ (Fig. $1 \mathrm{E}$, inset). Specificity of $s A \beta_{1-40}$ binding was reflected by the minimal influence of $150 \mathrm{nM}$ reverse $\mathrm{sA} \beta_{40-1}$ peptide. Scatchard analysis of the binding data at $4{ }^{\circ} \mathrm{C}$ indicated the presence of two independent sA $\beta_{1-40}$ binding sites (Fig. $1 E$, main graph). The nonlinear regression analysis indicated a high-affinity binding site with a dissociation constant $K_{\mathrm{d}}^{1}$ of $7.8 \pm 1.2 \mathrm{nM}$ (estimate \pm SD) and binding maximum $\left(B_{\text {max }}^{1}\right)$ of $3.75 \pm 0.52 \mathrm{pmol} / \mathrm{mg}$ of protein. The second class of binding sites was of lower affinity $\left(K_{\mathrm{d}}^{2}\right.$ of $52.8 \pm 6.2 \mathrm{nM})$ and higher capacity $\left(B_{\text {max }}^{1}\right.$ of $15.75 \pm 0.25$ $\mathrm{pmol} / \mathrm{mg}$ of protein). As illustrated in Fig. $1 F$, the amount of sA $\beta_{1-40}$ that was internalized by HBMECs (i.e., resistant to re-
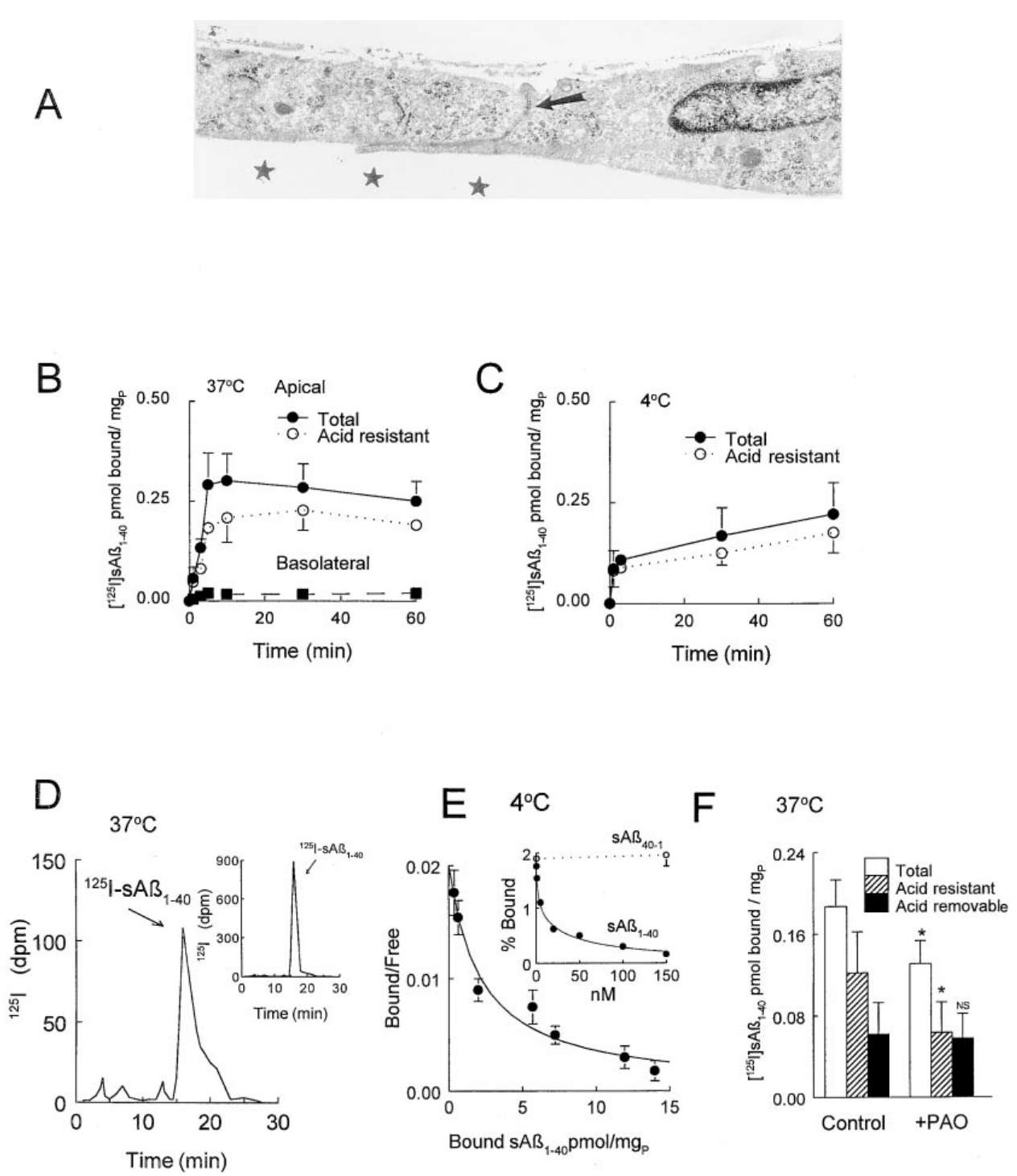

low-affinity, high-capacity sites, $K^{2}{ }_{\mathrm{d}}$ was estimated at $52.8 \pm 6.2 \mathrm{nM}$, and $B^{2}{ }_{\max }=15.75 \pm 0.25 \mathrm{pmol} / \mathrm{mg}$ of protein. $(F)$ Effect of $20 \mu \mathrm{M}$ PAO on the internalization of ${ }^{125} \mathrm{I}-\mathrm{sA} \beta_{1-40}$. The total amount of ${ }^{125} \mathrm{I}-\mathrm{sA} \beta_{1-40}$ bound to the HBMECs, as well as the extracellular (acid wash removable) and intracellular (acid wash resistant) components were examined following a 30 -min incubation at $37^{\circ} \mathrm{C}$. $* P<0.05$, for total and acid resistant ${ }^{125} \mathrm{I}$ sA $\beta_{1-40},{ }^{\text {ns }}$ nonsignificant for acid removable ${ }^{125} \mathrm{I}-\mathrm{sA} \beta_{1-40}$ in PAO-treated compared with respective controls, by Student's $t$ test. $(B, C, E$, and $F$ ) The values are mean \pm SD of three monolayers determined in triplicate; $\mathrm{mg}_{\mathrm{p}}=\mathrm{mg}$ of protein. 
moval by acid wash) was significantly reduced by $20 \mu \mathrm{M}$ PAO, an endocytic inhibitor. In all experiments, the HBMEC uptake of simultaneously exposed ${ }^{14} \mathrm{C}$-inulin was barely above the background level, indicating the absence of a nonspecific leak into the cells and minimal entrapping of the tracer in the medium between the cells at the sites of junctional complexes.

Transendothelial transport of $\mathrm{sA} \beta_{1-40}$ was asymmetrical in the apical-to-basolateral direction. At $37^{\circ} \mathrm{C}$, transport from the upper to the lower chamber was significantly higher for intact ${ }^{125} \mathrm{I}-\mathrm{sA} \beta_{1-40}$ (TCA-precipitable) than for ${ }^{14} \mathrm{C}$-inulin, an extracellular space marker transported across the monolayer by a nonspecific diffusion (leakage) through the intercellular pores or junctions (Fig. $2 A$ ). In contrast, basolateral-to-apical transport of sA $\beta_{1-40}$ was comparable to inulin. Apical-to-basolateral transport of $\mathrm{sA} \beta_{1-40}$ across the endothelial monolayer corrected for the nonspecific leakage (inulin transport) was time dependent and sensitive to reduced temperature (Fig. $2 \mathrm{~B}$ ). When corrected for the nonspecific leakage, basolateral-to-apical transport of ${ }^{125} \mathrm{I}-\mathrm{sA} \beta_{1-40}$ was undetectable. Figure $2 C$ illustrates dose-dependent inhibition of ${ }^{125} \mathrm{I}-\mathrm{sA} \beta_{1-40}$ PS product (corrected for the nonspecific leakage) by increasing concentrations of unlabeled $\mathrm{sA} \beta_{1-40}$ in the apical (upper) chamber. The specificity of transport was shown by the lack of effect of $\mathrm{sA} \beta_{40-1}$. The Michaelis-Menten analysis revealed the $K_{\mathrm{m}}$ of $45 \pm 9 \mathrm{nM}$ and $V_{\max }$ of $2.10 \pm 0.35 \mathrm{pmol} / \mathrm{min} / \mathrm{mg}$ of protein (Fig. $2 D)$.

Figure $3 A$ indicates that anti-RAGE antibody $(20 \mu \mathrm{g} / \mathrm{ml})$ inhibits by about $63 \%$ the binding of ${ }^{125} \mathrm{I}-\mathrm{sA} \beta_{1-40}$ to the apical side of the BBB. AcLDL at a maximal inhibitory concentration of $800 \mu \mathrm{g} / \mathrm{ml}$ was able to produce about $32 \%$ inhibition of ${ }^{125} \mathrm{I}-\mathrm{sA} \beta_{1-40}$ binding, and a further increase in the AcLDL con- centration did not result in a greater decrease of ${ }^{125} \mathrm{I}-\mathrm{sA} \beta_{1-40}$ binding (data not shown). Maximal inhibition of ${ }^{125} \mathrm{I}-\mathrm{sA} \beta_{1-40}$ binding by anti-RAGE + AcLDL was $95.6 \%$. As shown by the inset, there was a progressive dose-dependent inhibition of ${ }^{125} \mathrm{I}-\mathrm{sA} \beta_{1-40}$ binding by anti-RAGE at $4^{\circ} \mathrm{C}$ in the presence of a maximal inhibitory concentration of AcLDL; the maximal inhibition with anti-RAGE was achieved at $20 \mu \mathrm{g} / \mathrm{ml}$. Figure $3 B$ shows that at $37^{\circ} \mathrm{C}$, anti-RAGE $(20 \mu \mathrm{g} / \mathrm{ml})$ inhibits apicalto-basolateral transport of ${ }^{125} \mathrm{I}-\mathrm{sA} \beta_{1-40}$ by about $36 \%$, and further increase in the anti-RAGE concentration did not produce greater inhibition (Fig. 3 B, inset). The addition of AcLDL at maximal concentrations did not affect transcytosis of ${ }^{125} \mathrm{I}-\mathrm{sA} \beta_{1-40}$. The expression of RAGE and SR in the present HBMEC system was shown by immunocytochemistry (RAGE) and uptake of endothelial SR ligand, fluorescent DiI-AcLDL (Fig. 3, C and $D$ ). We previously reported that glycoprotein 330, gp330/ megalin, is expressed at the $\mathrm{BBB}$, but does not participate in binding and transport of free $A \beta_{1-40}$ (38). This has been confirmed in the present BMEC model and the expression of gp330/megalin shown by immunocytochemistry with mouse monoclonal 1H12 anti-human anti-gp330 antibodies, kindly provided by R. McCluskey, Harvard University (data not shown; Stins et al., unpublished observations). Figure $3 E$ illustrates that unlabeled LDL (low density lipoproteins) at concentrations as high as $800 \mu \mathrm{g} / \mathrm{ml}$ does not affect the uptake of ${ }^{125} \mathrm{I}-\mathrm{AcLDL}(1 \mathrm{nM})$ exposed for $1 \mathrm{~h}$ to the apical side of the HBMEC monolayers, indicating that LDL receptor does not participate in uptake of AcLDL, as shown previously $(39,40)$.

Our results with cultured HBMECs led us to analyze directly the potential involvement of RAGE and SR in cellular handling of $\mathrm{sA} \beta_{1-40}$ using transfected cell systems in which the

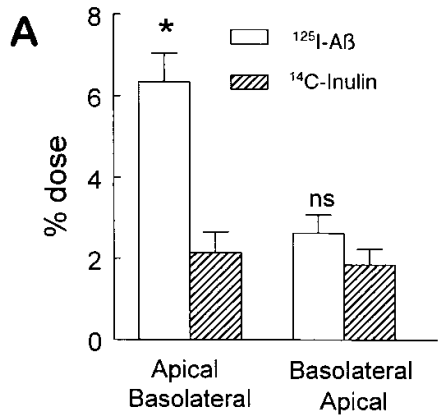

B

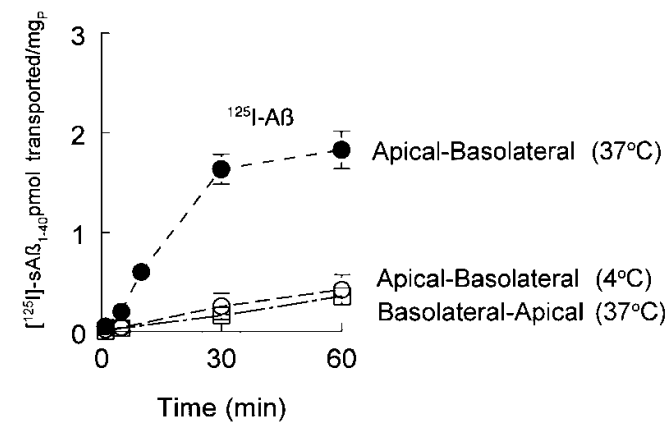

C

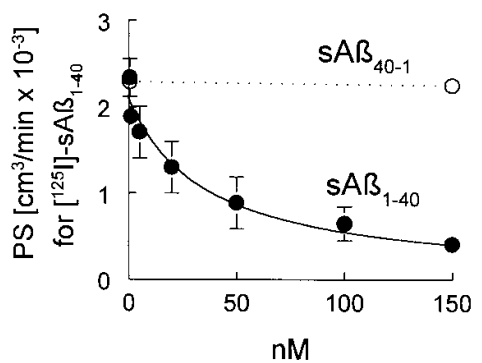

Figure 2. Asymmetrical transendothelial transport of sA $\beta_{1-40}$ across HBMEC monolayers. $(A)^{125} \mathrm{I}-\mathrm{sA} \beta_{1-40}(0.5 \mathrm{nM})$ and ${ }^{14} \mathrm{C}$-inulin $(10 \mathrm{nM})$ were added to either apical or basolateral compartment of HBMEC for $30 \mathrm{~min}$ at $37^{\circ} \mathrm{C}$. Ordinate, percent of the radioactivity dose of ${ }^{125} \mathrm{I}$ sA $\beta_{1-40}$ (open bars) and ${ }^{14} \mathrm{C}$-inulin (patterned bars) transported from either apical-to-basolateral (left), or basolateralto-apical (right) compartment. $* P<$ $0.05,{ }^{\mathrm{n} s}$ nonsignificant for ${ }^{125} \mathrm{I}-\mathrm{sA} \beta_{1-40}$ and ${ }^{14} \mathrm{C}$-inulin, by Student's $t$ test. (B) Time and temperature dependence of apicalto-basolateral ${ }^{125} \mathrm{I}-\mathrm{sA} \beta_{1-40}$ transport corrected for the nonspecific leakage of tracers (solid points at $37^{\circ} \mathrm{C}$; open points at $4^{\circ} \mathrm{C}$ ). Basolateral-to-apical transport (open squares) was undetectable at $37^{\circ} \mathrm{C}$. (C) Inhibition of the permeability-surface area (PS) product of ${ }^{125} \mathrm{I}$-sA $\beta_{1-40}$ (transport in apical-to-basolateral direction) by increasing concentrations of unlabeled $\mathrm{sA} \beta_{1-40}$ at the apical side, and lack of the effect of sA $\beta_{40-1}$. $(D)$ Apical-to-basolateral saturable influx $\left(J_{\text {in }}\right)$ of ${ }^{125} \mathrm{I}$-sA $\beta_{1-40}$ determined at $37^{\circ} \mathrm{C}$ in the presence of increasing concentrations of unlabeled sA $\beta_{1-40} .(B, C$, and $D)$ The values for intact ${ }^{125} \mathrm{I}$-sA $\beta_{1-40}$ were corrected for the diffusion across intercellular junctions (nonspecific leakage of tracer) by subtracting corresponding values for ${ }^{14} \mathrm{C}$-inulin. Values are mean $\pm \mathrm{SD}$ of three monolayers determined in triplicate; $\mathrm{mg}_{\mathrm{p}}=\mathrm{mg}$ of protein. 

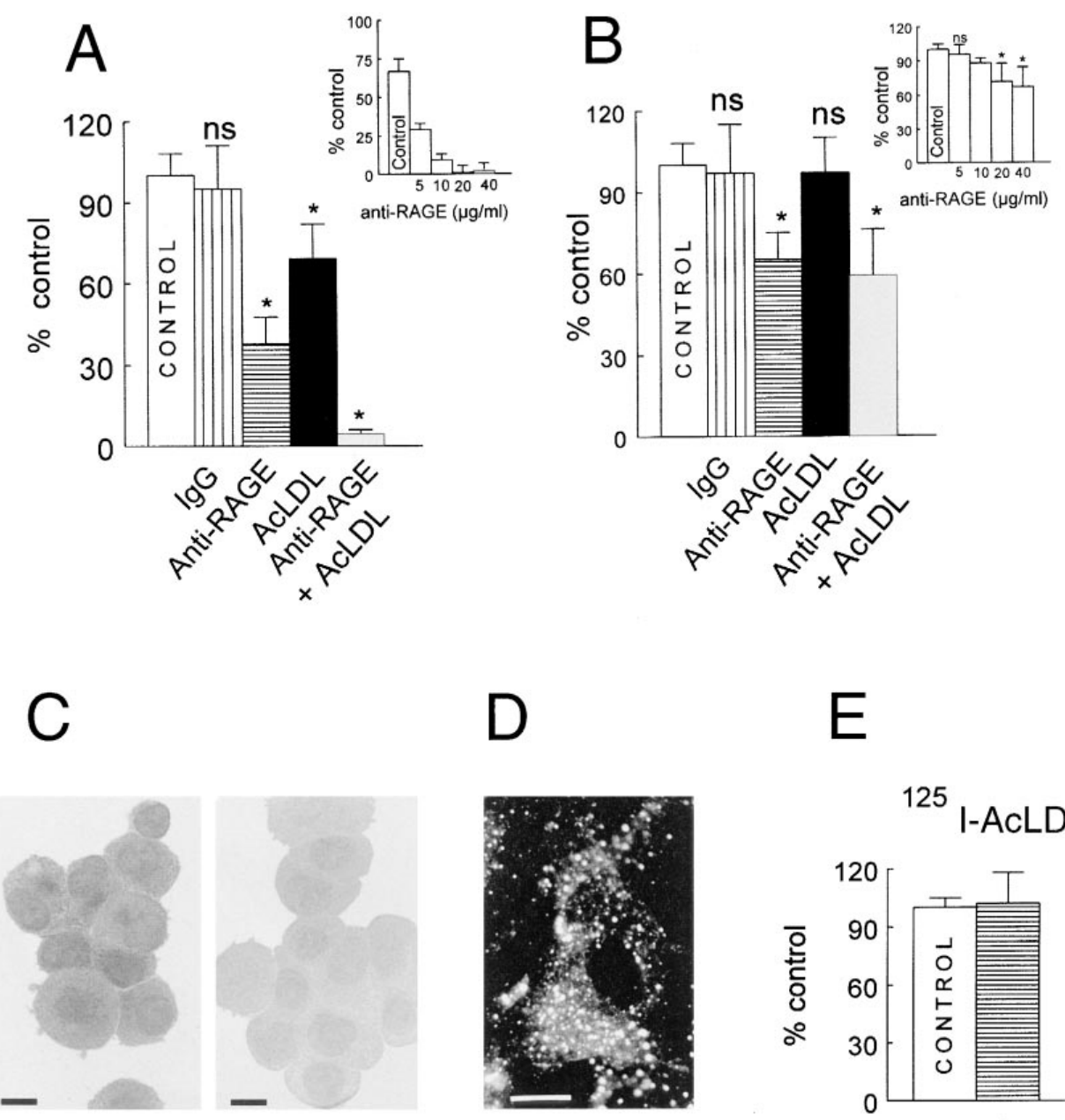
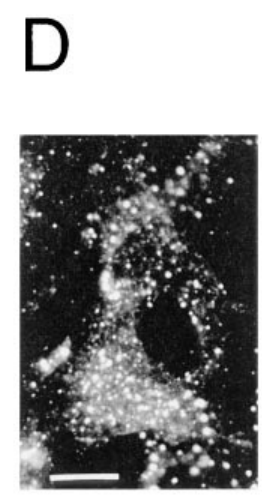

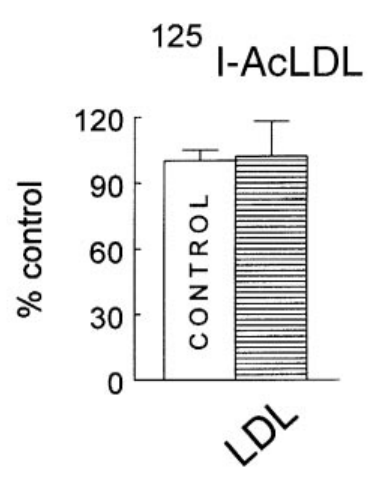

Figure 3. $(A)$ Binding of ${ }^{125} \mathrm{I}-\mathrm{sA} \beta_{1-40}$ to the apical side of the $\mathrm{BBB}$ in the presence of anti-RAGE and AcLDL (SR ligand). The HBMEC monolayers were treated for $30 \mathrm{~min}$ at $4^{\circ} \mathrm{C}$ before and during $\left[{ }^{125} \mathrm{I}\right]-$ sA $\beta_{1-40}$ incubation with anti-RAGE and AcLDL. The main graph shows maximal inhibitions of $\left[{ }^{125} \mathrm{I}\right]-\mathrm{sA} \beta_{1-40}$ binding by anti-RAGE $(20 \mu \mathrm{g} / \mathrm{ml}$; horizontally patterned bar) and AcLDL ( $800 \mu \mathrm{g} / \mathrm{ml}$; black bar $)$ separately, or together (gray bar); control uptake (open bar) and no effect of normal rabbit $\mathrm{IgG}$ (vertically patterned bar). The inset illustrates the effect of increasing anti-RAGE concentration on $\left[{ }^{125} \mathrm{I}\right] \mathrm{sA} \beta_{1-40}$ binding in the presence of maximal inhibitory concentration of AcLDL $(800 \mu \mathrm{g} /$ $\mathrm{ml}$ ). (B) Apical-to-basolateral transendothelial transport of ${ }^{125} \mathrm{I}$ sA $\beta_{1-40}$ corrected for nonspecific leakage of tracers in the presence of anti-RAGE and AcLDL. The HBMEC monolayers were treated for $30 \mathrm{~min}$ at $37^{\circ} \mathrm{C}$ before and during [ $\left.{ }^{125} \mathrm{I}\right] \mathrm{sA} \beta_{1-40}$ incubation with antiRAGE and AcLDL. The main graph shows inhibition of $\left[{ }^{125} \mathrm{I}\right] \mathrm{sA} \beta_{1-40}$ transport by anti-RAGE $(20 \mu \mathrm{g} / \mathrm{ml}$; horizontally patterned bar) in comparison with control transport values (open bar), and no effect of rabbit IgG (vertically patterned bar). The lack of AcLDL effect either alone $(800 \mu \mathrm{g} / \mathrm{ml}$; patterned bar $)$ or together with anti-RAGE (black bar) is also shown. The inset illus-

trates the effect of increasing anti-RAGE concentration on $\left[{ }^{125} \mathrm{I}\right] \mathrm{sA} \beta_{1-40}$ transport. $* P<0.05$, ${ }^{\mathrm{ns}}$ nonsignificant for $\left[{ }^{125} \mathrm{I}\right] \mathrm{sA} \beta_{1-40}$ in the absence and presence of anti-RAGE, AcLDL, or anti-RAGE + AcLDL, by Student's $t$ test. $(C)$ Immunoctytochemical detection of RAGE in HBMEC with anti-RAGE (1:200) antibody (left) and negative control ( $r i g h t$, omission of primary antibody). (D) Uptake of fluorescent DiI-AcLDL (10 $\mu \mathrm{g} / \mathrm{ml})$ by HBMEC. (E) Uptake of ${ }^{125} \mathrm{I}$-AcLDL $(1 \mathrm{nM})$ by HBMEC (open bar, control) at $37^{\circ} \mathrm{C}$ and exposed for $1 \mathrm{~h}$ to the apical side of the HBMEC monolyears is not affected with $800 \mu \mathrm{g} / \mathrm{ml}$ unlabeled LDL (horizontally patterned bar). $(A, B$, and $E$ ) Control values were arbitrarily set as $100 \%$. $(C$ and $D)$ The bar is $5 \mu \mathrm{m}$. Values are means \pm SD of three monolayers determined in triplicate.

A $\beta$-cellular interactions were mediated principally by the latter two receptors. $\mathrm{CHO}$ cells transiently transfected with pcDNA3/RAGE displayed expression of RAGE, by immunoblotting and immunocytochemistry, compared with mocktransfected controls (Fig. $4 A, B I-I I$ ). Transiently transfected $\mathrm{CHO}$ cells demonstrated specific binding of ${ }^{125} \mathrm{I}-\mathrm{sA} \beta_{1-40}$ compared with mock-transfected controls (Fig. $4 \mathrm{C}$ ). Cells were briefly exposed to paraformaldehyde $(2 \%)$ to prevent internalization during binding assays performed at $37^{\circ} \mathrm{C}$, and RAGE-dependent ${ }^{125} \mathrm{I}$-sA $\beta_{1-40}$ binding was dose-dependent with $K_{\mathrm{d}} \simeq 72.0 \pm 42.1 \mathrm{nM}$. Cell-associated radioactivity was restricted to the surface, as shown by complete elution of specifically bound ${ }^{125} \mathrm{I}-\mathrm{sA} \beta_{1-40}$ with heparin under these conditions (Fig. $4 D$, fixed cell). If heparin solution was followed by dissolution of the cells in NP-40 containing buffer, no additional specifically bound tracer was recovered using paraformaldehydetreated cells. In contrast, when experiments were performed at $37^{\circ} \mathrm{C}$ without paraformaldehyde, endocytosis of cell-associated ${ }^{125} \mathrm{I}-\mathrm{s} A \beta_{1-40}$ resulted in two pools of ligand (Fig. $4 \mathrm{D}$, unfixed cell); most ligand was still on the cell surface ( $\sim 82-83 \%$ by 3 h). However, a component of specifically bound ligand was present in a heparin-resistant, NP-40-elutable pool $(\sim 17-$ $18 \%)$. Immunocytochemistry was performed using an antibody specific for $A \beta_{1-40}$. To visualize internalized ligand, following the incubation period at $37^{\circ} \mathrm{C}$, cell surface sA $\beta_{1-40}$ was eluted with heparin-containing buffer. The absence of surfaceassociated ligand following heparin treatment of RAGE-transfected $\mathrm{CHO}$ cells was confirmed by immunocytochemistry of nonpermeabilized cells (Fig. $4 E, I$ ). Next, after heparin elution, cultures were permeabilized with NP-40, and the presence of a pool of $\mathrm{sA} \beta_{1-40}$ present in a granular pattern was observed (Fig. $4 E, I I$ ). Thus, the latter sA $\beta_{1-40}$ represented internalized ligand.

Similar radioligand and internalization studies were performed using stably transfected Bowes cells overexpressing SR type A. This scavenger receptor was selected for our studies in view of its identification in brain microvasculature (39). Surface binding was evaluated at $37^{\circ} \mathrm{C}$ using cells briefly exposed 
A

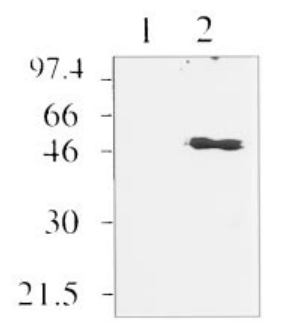

C
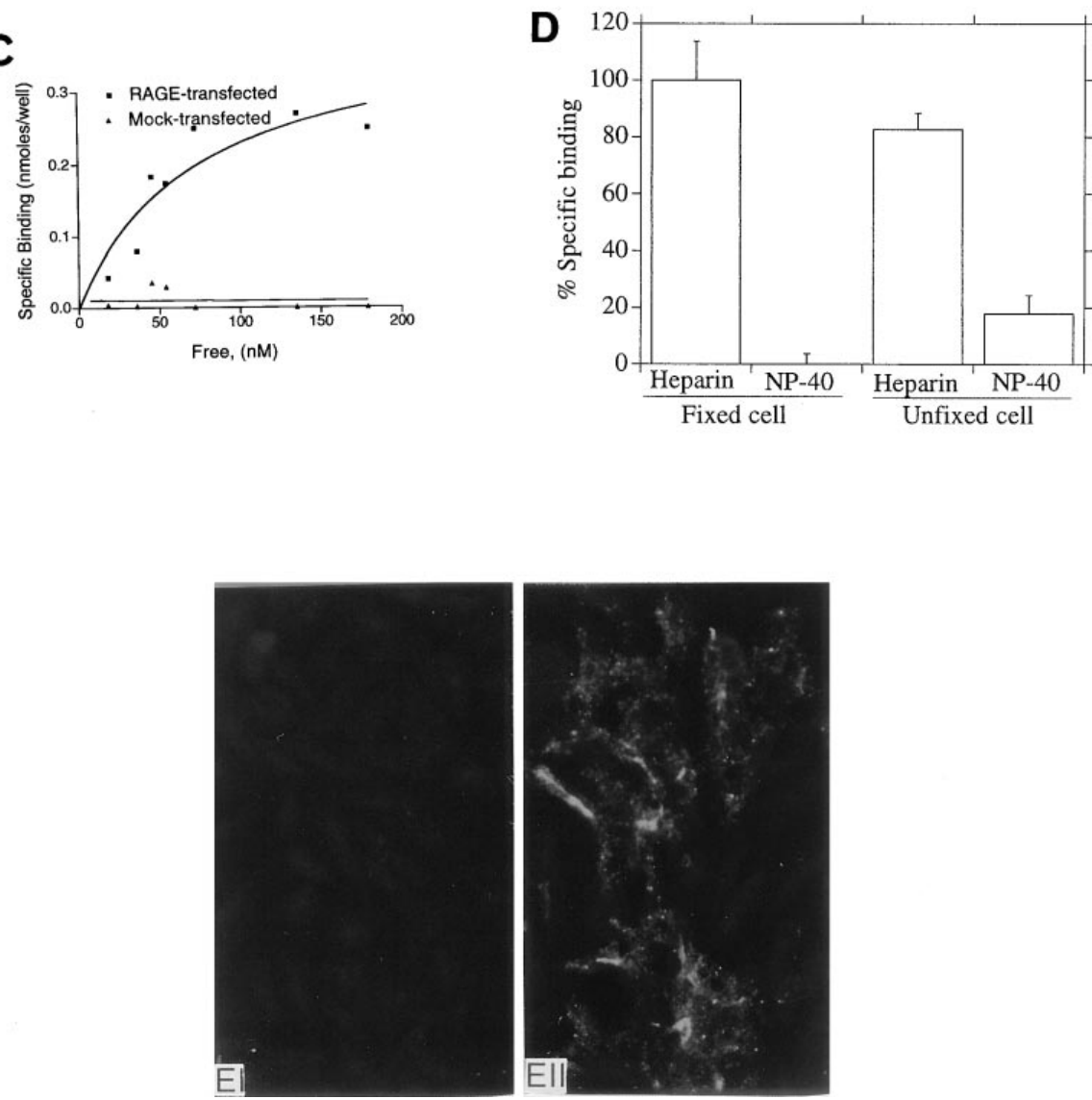

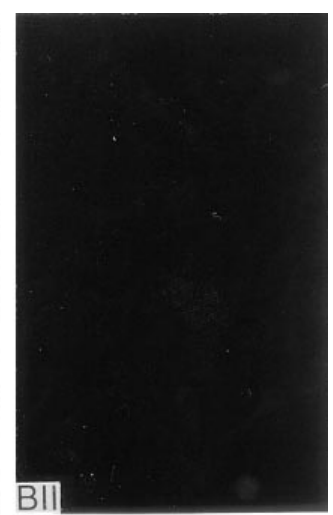

Figure 4. Interaction of RAGE with $\mathrm{sA} \beta_{1-40}$ : studies on RAGE-transfected $\mathrm{CHO}$ cells. (A) Immunoblotting. $\mathrm{CHO}$ cells were transiently transfected with pcDNA3/RAGE (lane 2) or pcDNA3 alone (lane 1), lysates were prepared, and subjected to reduced SDS-PAGE $(10 \% ; 50 \mu \mathrm{g}$ total protein/ lane) followed by immunoblotting with rabbit anti-human RAGE IgG $(4 \mu \mathrm{g} / \mathrm{ml}$ [47]) and visualization of primary antibody with peroxidase-conjugated anti-rabbit IgG and the ECL system. (BI-BII) Immunocytochemical visualization of RAGE. RAGE-transfected $(B I)$ and mock-transfected $(B I I)$ CHO cells were fixed in paraformaldehyde $(2 \%)$ alone and then incubated with rabbit anti-RAGE IgG $(6.5 \mu \mathrm{g} /$ $\mathrm{ml}$ ) followed by FITC-conjugated goat anti-rabbit IgG. Magnification, 400. (C) Dose dependence of ${ }^{125} \mathrm{I}$-sA $\beta_{1-40}$ binding. RAGE-transfected CHO cells were incubated with the indicated concentrations of ${ }^{125} \mathrm{I}-\mathrm{sA} \beta_{1-40}$ alone or in the presence of 100 fold excess unlabeled ligand. Specific binding (total minus nonspecific binding) is plotted versus free (assumed to be the same as added) ligand. Binding was analyzed by nonlinear least squares. $(D)$ Identification of cell surface-associated and internalized ${ }^{125} \mathrm{I}$-sA $\beta_{1-40}$. RAGE-transfected $\mathrm{CHO}$ cells were either briefly treated with paraformaldehyde ( $2 \%$; fixed cells) or incubated in buffer alone (unfixed cells), followed by exposure to ${ }^{125} \mathrm{I}-\mathrm{sA} \beta_{1-40}(54 \mathrm{nM})$ alone or in the presence of 100 -fold excess unlabeled $\mathrm{sA} \beta_{1-40}$ for $2 \mathrm{~h}$ at $37^{\circ} \mathrm{C}$. Cultures were then washed, and exposed to heparincontaining elution buffer (heparin) followed by NP-40-containing elution buffer (NP-40). Specifically bound ligand under each condition is shown as a percentage of total specific binding. (EI-EII) Visualization of cell-associated sA $\beta_{1-40}$. RAGEtransfected $\mathrm{CHO}$ cells were incubated with sA $\beta_{1-40}$ at $37^{\circ} \mathrm{C}$. Cells were exposed to heparin containing buffer to elute surface bound $\mathrm{A} \beta(E I)$, or were exposed to heparin followed by permeabilization with NP40 containing buffer $(E I I)$. Immunocytochemistry to visualize $A \beta$ was performed as described in the text. to paraformaldhyde as described above. Compared with mocktransfected controls, SR-transfected Bowes cells displayed specific binding of ${ }^{125} \mathrm{I}-\mathrm{sA} \beta_{1-40}$. Binding was dose dependent, displaying $K_{\mathrm{d}} \simeq 101.7 \pm 32.9 \mathrm{nM}$ (Fig. $5 \mathrm{~A}$ ). Pretreatment of cultures with paraformaldehyde prevented internalization of cell-bound ${ }^{125} \mathrm{I}-\mathrm{s} A \beta_{1-40}$, as complete elution of specifically bound ligand was observed with heparin (Fig. $5 \mathrm{~B}$, fixed cell). Under these conditions, no increments in specifically bound ${ }^{125} \mathrm{I}$ $\mathrm{sA} \beta_{1-40}$ was observed following NP-40 elution. In contrast, experiments with live (i.e., unfixed) cells and ${ }^{125} \mathrm{I}-\mathrm{sA} \beta_{1-40}$ performed at $37^{\circ} \mathrm{C}$ demonstrated the appearance of a sizeable pool of heparin-resistant cell-associated tracer. Following heparin elution of cell surface-bound tracer, NP-40 elution recovered an additional $\sim 70 \%$ of total specifically cell-associated radioactivity. Immunocytochemistry was used to confirm the presence of internalized $A \beta$. Following incubation of cultures with sA $\beta_{1-40}$ at $37^{\circ} \mathrm{C}$, cultures were exposed to heparin to elute surface-bound ligand (Fig. $5 C, I$ ). Subsequent permeabilization of these cells with NP-40 resulted in the appearance of a pool of sA $\beta_{1-40}$ in a granular pattern (Fig. $\left.5 C, I I\right)$ which represented internalized ligand.

\section{Discussion}

These studies indicate that $\mathrm{sA} \beta_{1-40}$ is bound and internalized at the apical side of the HBMECs cultured on membrane inserts 


\section{A}
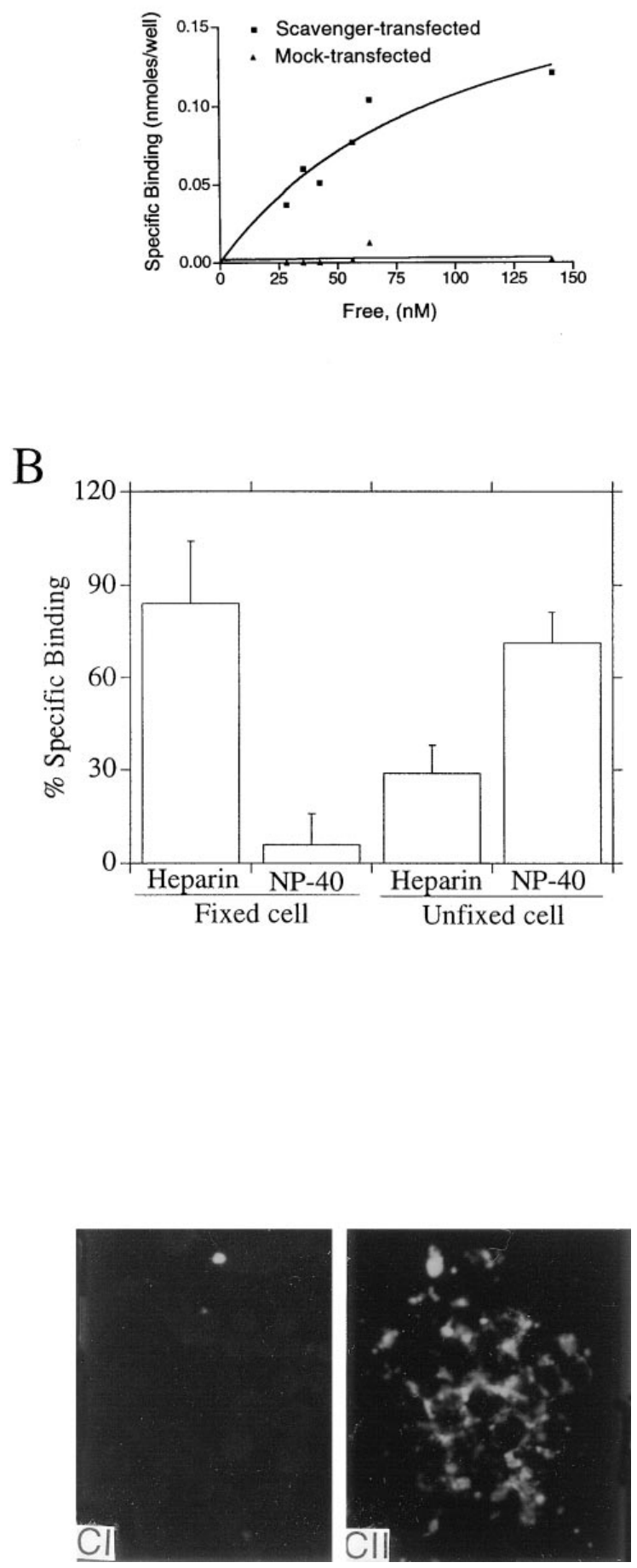

Figure 5. Interaction of SR with $\mathrm{SA} \beta_{1-40}$; studies on SR-transfected Bowes cells. $(A)$ Dose-dependence of ${ }^{125} \mathrm{I}$-sA $\beta_{1-40}$ binding. SR-transfected Bowes cells were incubated with the indicated concentrations of ${ }^{125} \mathrm{I}$-sA $\beta_{1-40}$ alone or in the presence of 100 -fold excess of unlabeled ligand. Specific binding was determined and analyzed as described under Fig. $4 C$. (B) Identification of surface-associated and internalized ${ }^{125}$ I-sA $\beta_{1-40}$. SR-transfected Bowes cells were either briefly treated with paraformaldehyde (fixed cells) or incubated in buffer alone (unfixed cells), followed by exposure to ${ }^{125} \mathrm{I}-\mathrm{sA} \beta_{1-40}$ as under Fig. $4 D$. (C) Visualization of cell-associated $\mathrm{sA} \beta_{1-40}$. SR-transfected Bowes cells were incubated with $\mathrm{sA} \beta_{1-40}$ at $37^{\circ} \mathrm{C}$ for $2 \mathrm{~h}$. Cells were by two specific acceptor sites. The binding constant of the high-affinity sA $\beta_{1-40} \mathrm{BBB}$ sites $\left(K_{\mathrm{d}}=7.8 \mathrm{nM}\right)$ was comparable to $K_{\mathrm{d}}$ 's determined for human brain capillary receptors for peptides such as leptin, transferrin, insulin, and insulin-like growth factors (41). The binding maximum of the high-affinity $\mathrm{sA} \beta_{1-40} \mathrm{BBB}$ sites was at least an order of magnitude higher than for the peptide hormones. The second class of lower affinity sites $\left(K_{\mathrm{d}}=52.8 \mathrm{nM}\right)$ exhibited 4.2 -fold greater binding capacity than the high-affinity sites. The inhibition studies indicated that RAGE and SR are receptors involved in binding of free $\mathrm{sA} \beta_{1-40}$ at the apical side of the $\mathrm{BBB}$. In contrast, the $\mathrm{BBB}$ binding and transport of $\mathrm{A} \beta$ complexed to apolipoprotein $\mathbf{J}$ (apoJ) is mediated via gp330/megalin (38), and this receptor does not recognize the free form of peptide. The specific transport system mediating asymmetrical apicalto-basolateral transcytosis of free $\mathrm{sA} \beta_{1-40}$ was also found. The affinity constant of human BBB sA $\beta_{1-40}$ transporters $(45 \mathrm{nM})$ compares well with the initially reported $K_{\mathrm{m}}$ of $42 \mathrm{nM}$ for saturable $\mathrm{sA} \beta_{1-40} \mathrm{BBB}$ transport in vivo in rodents (20). Transport was partially sensitive to RAGE blockade but also involved a RAGE-independent component, possibly a novel cellular "chaperone" transporter protein for $\mathrm{sA} \beta$.

The lack of specific $\mathrm{sA} \beta_{1-40}$ binding at the basolateral side of the HBMEC monolayer suggests that all specific high-affinity binding sites at normal human $\mathrm{BBB}$ may be located at the apical side, similar as for insulin (30). The polarity of the BBB in present HBMEC model $(24,25)$ seems to be preserved (42), as indicated by cellular distribution of the A amino acid transporter and enrichment of the sodium pump at the basolateral side (Stins, M., S. Jovanovic, J.B. Mackic, K.S. Kim, and B.V. Zlokovic, unpublished observations). Previous work on in vitro BBB models indicated that several peptides (e.g., vasopressin, atrial natriuretic peptide) in contrast to $\mathrm{sA} \beta_{1-40}$ are taken up by specific mechanisms only at the basolateral side followed by transendothelial transport and exocytosis at the apical side, while apical-to-basolateral transport was undetectable (16). In the absence of significant brain-to-blood transport of $\mathrm{sA} \beta$, rapid clearance of $\mathrm{sA} \beta_{1-40}$ from the CSF, as reported in rodents (43), could be important to maintaining low concentrations of $\mathrm{sA} \beta$ in brain extracellular fluids. It is likely that present in vitro findings could be extrapolated to humans in vivo, since the in vivo evidence in rodents and nonhuman primates confirms the net $\mathrm{sA} \beta_{1-40} \mathrm{BBB}$ transport from bloodto-brain $(20-23,44)$.

In addition to clearance, it is likely that brain metabolism serves to maintain low levels of $\mathrm{sA} \beta$ in cerebrovascular and brain interstitium to balance the effects of $\mathrm{BBB}$ transport of circulating sA $\beta$ and local brain production of peptide, which both would tend to accumulate $\mathrm{sA} \beta$ in brain. In contrast to metabolism of sA $\beta_{1-40}$ in brain in vivo $(22,44)$, there was minimal degradation of peptide by the HBMECs. The failure in degradation mechanisms combined with an enhanced apicalto-basolateral sA $\beta$ transport, as in senescent squirrel monkey (22), may enhance the development of cerebral amyloid angiopathy and increase $\mathrm{sA} \beta$ accumulation in brain. Whether this same situation applies to $\mathrm{BBB}$ mechanisms in $\mathrm{AD}$ remains to

exposed to heparin containing buffer to elute surface bound $\mathrm{A} \beta(C I)$, or were exposed to heparin followed by permeabilization with NP-40 containing buffer $(C I I)$. Immunocytochemistry to visualize $A \beta$ was performed as described in the text. 
be elucidated. It has been suggested that $A \beta_{1-42}$ produced in brain may favor amyloid "nucleation" (45) along with other components, e.g., zinc and apoE, to accumulate soluble sA $\beta_{1-40}$ from blood and CSF $(1,2,46)$. At critical levels (47), and in the presence of other predisposing factors (e.g., apoE4 genotype, mutations in presenilin 1 and 2 genes, and mutations in amyloid- $\beta$ protein precursor gene) (1) sA $\beta$ may precipitate as amyloid fibril in the vascular wall or in brain parenchyma, could exert its cytotoxic effects (3-5) and contribute to neuronal loss and the development of AD pathology (1).

Present findings support the vascular theory by demonstrating that brain endothelial distribution of $A \beta$ receptors at the apical side of the BBB could be responsible for interaction of circulating $\mathrm{sA} \beta$ with the vessel wall, both for removal of this peptide from plasma and possibly for inducing endothelial cell injury $(48,49)$. The list of specific receptor- and/or carriermediated BBB mechanism(s) participating in cerebrovascular accumulation, deposition, and brain transfer of blood-borne $A \beta_{1-40}$, the Dutch mutant vasculotropic peptide (A $\beta Q$ ) (22) and $A \beta_{1-42}$ free or complexed with apoJ and apoE4 (21, 32, 38 ), and/or mediating vascular endothelial damage by $\mathrm{A} \beta(3,4$, 48, 49) includes gp330/megalin, RAGE, SR, low- and highdensity lipoprotein receptors, vascular adhesion molecules, endoplasmic reticulum-associated $A \beta$ binding protein (35) and possibly yet unidentified receptors/transporters.

The BBB permeability to A $\beta$-apoJ complex via gp330/ megalin receptor was among the highest ever measured for peptides/proteins at the BBB (38). The gp330/megalin at the BBB works with the maximal transport capacity at physiological plasma concentrations of apoJ (50), but despite its extremely high affinity for $A \beta-a p o J$, this receptor does not transport or bind free $\mathrm{A} \beta$ at the $\mathrm{BBB}$ (38). The present study reveals that RAGE and SR are responsible for $\mathrm{BBB}$ binding of free $A \beta$. Both the RAGE and SR are well known as receptors with multiple functions including cellular endocytosis and transcytosis of macromolecules $(3,51)$. Our studies support the potential of RAGE and SR type A to interact with sA $\beta_{1-40}$ mediating surface binding and, potentially, subsequent cellular processing of the ligand. In terms of endocytosis of cell-bound $A \beta$, SR type A appears to be much more efficient than RAGE. However, RAGE may function to pass off $A \beta$ to other binding sites mediating passage through the endothelial monolayer by mechanisms not adequately modeled in our transfected cell system. Since the transfection studies were performed in $\mathrm{CHO}$ and Bowes cells to examine separately the contributions of RAGE and SR, respectively, rather than endothelium, quantitative comparisons of the data are difficult to make. Clearly, the crucial test of our hypothesis concerning receptor-dependent interactions of intravascular $A \beta$ will be in in vivo studies using specific reagents to block contribution individually of each receptor to cellular handling of $A \beta$.

With respect to $\mathrm{A} \beta \mathrm{BBB}$ transcytosis, the present study suggests the involvement of RAGE but also indicates a possible role for a RAGE-independent component that may be a novel cytosolic $A \beta$ "chaperone" transporter protein. The molecular nature of this chaperone transporter protein remains to be elucidated, as well as its functional relationship with RAGE. It is possible that both RAGE and chaperone protein exhibit similar kinetic affinities to transport $A \beta$ in the present HBMEC model, so that Michealis-Menten analysis revealed a single transport site. Alternatively, the affinity of one of these components may be at the lower limit of sensitivity with the present method, and molecular isolation and characterization from cytosolic and cell membrane fractions should demonstrate whether the transporter protein is different from known A $\beta$-binding proteins and/or receptors. The distribution of cerebrovascular endothelial receptors for free and bound forms of $\mathrm{A} \beta$ in $\mathrm{AD}$ is unknown, but it is likely that they could play important roles in $\mathrm{A} \beta$ vascular binding and transport, and therefore influence the development of cerebrovascular amyloidosis and vascular injury.

\section{Acknowledgments}

This work was supported by National Institutes of Health grants NS34467 and AG-14526 to B.V. Zlokovic and AG-05891 to B. Frangione. J. Ghiso is a recipient of the New Investigator Development Award, AHA, New York City Affiliate. M. Calero is the recipient of the NATO fellowship.

\section{References}

1. Wisniewski, T., J. Ghiso, and B. Frangione. 1997. Biology of A $\beta$ amyloid in Alzheimer's Disease. Neurobiol. Dis. 4:311-328.

2. Dickson, D.W. 1997. The pathogenesis of senile plaques. J. Neuropathol. Exp. Neurol. 56:321-339.

3. Mattson, M.P., and R.E. Rydel. 1996. Amyloid ox-tox transducers. Nature. 382:674-675.

4. Yan, S.D., X. Chen, J. Fu, M. Chen, H. Zhu, A. Roher, T. Slattery, L. Zhao, M. Nagashima, J. Morser, A. Migheli, et al. 1996. RAGE and amyloid- $\beta$ peptide neurotoxicity in Alzheimer's disease. Nature. 382:685-691.

5. El Khoury, J., S.E. Hickman, C.A. Thomas, L. Cao, S.C. Silverstein, and J.D. Loike. 1996. Scavenger receptor-mediated adhesion of microglia to $\beta$-amyloid fibrils. Nature. 382:716-719.

6. Citron, M., T.S. Diehl, G. Gordon, A.L. Biere, P. Seubert, and D.J. Selkoe. 1996. Evidence that the 42- and 40-amino acid forms of amyloid $\beta$ protein are generated from the $\beta$-amyloid precursor protein by different protease activities. Proc. Natl. Acad. Sci. USA. 93:13170-13175.

7. Seubert, P., C. Vigo-Pelfrey, F. Esch, M. Lee, H. Dovey, D. Davis, S. Sinha, M. Schlossmacher, J. Whaley, C. Swindlehurst, et al. 1992. Isolation and quantification of soluble Alzheimer's $\beta$-peptide from biological fluids. Nature. 359:325-327.

8. Shoji, M., T. Golde, J. Ghiso, T. Cheung, S. Estus, L. Shaffer, X.D. Cai, D. McKay, R. Tintner, B. Frangione, and S. Younkin. 1992. Production of the Alzheimer amyloid $\beta$ protein by normal proteolytic processing. Science. 258: 126-129.

9. Tabaton, M., M.G. Nunzi, R. Xue, M. Usiak, L. Autilio-Gambetti, and P. Gambetti. 1994. Soluble amyloid beta-protein is a marker of Alzheimer amyloid in brain but not in cerebrospinal fluid. Biochem. Biophys. Res. Commun. 200:1598-1603.

10. Suzuki, N., T. Iwatsubo, A. Odaka, Y. Ishibashi, C. Kitada, and Y. Ihara. 1994. High tissue content of soluble beta 1-40 is linked to cerebral amyloid angiopathy. Am. J. Pathol. 145:452-460.

11. Castaño, E.M., F. Prelli, C. Soto, R. Beavis, E. Matsubara, M. Shoji, and B. Frangione. 1996. The length of amyloid-beta in hereditary cerebral hemorrhage with amyloidosis, Dutch type. Implications for the role of amyloid- $\beta$ 1-42 in Alzheimer's disease. J. Biol. Chem. 271:32185-32191.

12. Masters, C.L., G. Simms, N.A. Weinman, G. Multhaup, B.L. McDonald, and K. Beyreuther. 1985. Amyloid plaque core protein in Alzheimer disease and Down syndrome. Proc. Natl. Acad. Sci. USA. 82:4245-4249.

13. Prior, R., D. Durso, R. Frank, I. Prikulis, S. Cleven, R. Ihl, and G. Pavlakovic. 1996. Selective binding of soluble $A \beta 1-40$ and $A \beta 1-42$ to a subset of senile plaques. Am. J. Pathol. 148:1749-1756.

14. Zlokovic, B.V. 1997. Can blood-brain barrier play a role in the development of cerebral amyloidosis and Alzheimer's disease pathology? Neurobiol. Dis. 4:23-26.

15. Pardridge, W.M. 1986. Receptor-mediated peptide transport through the blood-brain barrier. Endocr. Rev. 7:314-330.

16. Takakura, Y., K.L. Audus, and R.T. Borchardt. 1991. Blood-brain barrier: transport studies in isolated brain capillaries and in cultured brain endothelial cells. In Advances in Pharmacology, Volume 22. Academic Press, New York. 137-164.

17. Banks, W.A., A.J. Kastin, and C.M. Barrera. 1991. Delivering peptides to the central nervous system: dilemmas and strategies. Pharmacol. Res. 8: 1345-1350.

18. Banks, W.A., A.J. Horvath, and E.A. Michals. 1987. Carrier-mediated transport of vasopressin across the blood-brain barrier of the mouse. J. Neurosci. Res. 18:326-332. 
19. Zlokovic, B.V. 1995. Cerebrovascular permeability to peptides: manipulations of transport systems at the blood-brain barrier. Pharmacol. Res. 12: $1395-1406$.

20. Zlokovic, B.V., J. Ghiso, J.B. Mackic, J.G. McComb, M.H. Weiss, and B. Frangione. 1993. Blood-brain barrier transport of circulating Alzheimer's amyloid B. Biochem. Biophys. Res. Commun. 197:1034-1040.

21. Poduslo, J.F., G.L. Curran, J.J. Haggard, A.L. Biere, and D.J. Selkoe. 1997. Permeability and residual plasma volume of human, Dutch variant, and rat amyloid $\beta$-protein 1-40 at the blood-brain barrier. Neurobiol. Dis. 4:27-34.

22. Mackic, J.B., M.H. Weiss, W. Miao, J. Ghiso, M. Calero, J. Bading, B. Frangione, and B.V. Zlokovic. 1998. Cerebrovascular accumulation and increased blood-brain barrier permeability to circulating Alzheimer's amyloid $\beta$-peptide in aged squirrel monkey with cerebral amyloid angiopathy. J. Neurochem. 70:210-215.

23. Ghilardi, J.R., M. Catton, E.R. Stimson, S. Rogers, L.C. Walker, J.E. Maggio, and P.W. Mantyh. 1996. Intra-arterial infusion of $\left[{ }^{125} \mathrm{I}\right] \mathrm{A} \beta_{1-40}$ labels amyloid deposits in the aged primate brain in vivo. Neuroreport. 7:2607-2611.

24. Stins, M.F., F. Gilles, and K.S. Kim. 1997. Selective expression of adhesion molecules on human brain microvascular endothelial cells. J. Neuroimmunol. 76:81-90.

25. Persidsky, Y., M. Stins, D. Way, M.H. Witte, M. Weinand, K.S. Kim, P. Bock, H.E. Gendelman, and M. Fiala. 1997. A model for monocyte migration through the blood-brain barrier during HIV-1 encephalitis. J. Immunol. 158: 3499-3510.

26. Fiala, M., M.F. Stins, D.J. Looney, P. Shapshank, A. Diagne, M.C. Graves, D.L. Way, O. Martinez, M.H. Witte, M. Weinard, and K.S. Kim. 1997. Penetration of HIV-1 across a blood-brain barrier model is enhanced by tumor necrosis factor $\alpha$. Mol. Med. 3:553-564.

27. Olefsky, J.M., and M. Kao. 1982. Surface binding and rates of internalization of ${ }^{125} \mathrm{I}$-insulin in adipocytes and IM-9 lymphocytes. J. Biol. Chem. 257: 8667-8673.

28. Gibson, A.E., R.J. Noel, J.T. Herlihy, and W.F. Ward. 1989. Phenylarsine oxide inhibition of endocytosis: effects of asialofetuin internalization. Am. J. Physiol. 257:C182-C184.

29. Moss, A.L., and W.F. Ward. 1991. Multiple pathways for ligand internalization in rat hepatocytes I: effects of anoxia, phenylarsine oxide and monensin. J. Cell. Physiol. 149:313-318.

30. Miller, D.W., B.T. Keller, and R.T. Borchardt. 1994. Identification and distribution of insulin receptors on cultured bovine brain microvessel endothelial cells: possible function in insulin processing in the blood-brain barrier. $J$. Cell. Phys. 161:333-341.

31. Terasaki, T., K. Hirai, H. Sato, Y.S. Kang, and A. Tsuji. 1989. Absorptive-mediated endocytosis of a dynorphin-like analgesic peptide, E-2078 into the blood-brain barrier. J. Exp. Pharmacol. Ther. 251:352-357.

32. Martel, C.L., J.B. Mackic, E. Matsubara, S. Governale, C. Miguel, W. Miao, J.G. McComb, B. Frangione, J. Ghiso, and B.V. Zlokovic. 1997. Isoformspecific effects of apolipoproteins E2, E3, E4 on cerebral capillary sequestration and blood-brain barrier transport of circulating Alzheimer's amyloid $\beta . J$. Neurochem. 69:1995-2004.

33. Lowry, O.H., N.J. Rosebrough, A.L. Farr, and R.J. Randall. 1951. Protein measurement with the Folin phenol reagent. J. Biol. Chem. 193:265-275.

34. Feldman, H.A. 1972. Mathematical theory of complex ligand-binding systems of equilibrium: some methods for parameter fitting. Anal. Biochem. 48: 317-338.

35. Yan, S.D., J. Fu, C. Soto, X. Chen, H. Zhu, F. Al-Mohanna, K. Collison, A. Zhu, E. Stern, T. Saido, et al. 1997. ERAB: a novel intracellular amyloid- beta peptide binding protein which mediates neurotoxicity in Alzheimer's disease. Nature. 381:689-695.

36. Hsu, H.-Y., D. Hajjar, K. Khan, and D. Falcone. 1998. Ligand binding to macrophage scavenger receptor A induces urokinase-type plasminogen activator expression by a protein kinase-dependent signaling pathway. J. Biol. 273: $1240-1246$.

37. Klotz, I., and D. Hunston. 1984. Mathematical models for ligand receptor binding. J. Biol. Chem. 258:11442-11445.

38. Zlokovic, B.V., C.L. Martel, E. Matsubara, J.G. McComb, G. Zheng, R.T. McClusky, B. Frangione, and J. Ghiso. 1996. Glycoprotein 330/megalin: probable role in receptor-mediated transport of apolipoproetin $\mathrm{J}$ alone and in complex with Alzheimer's disease amyloid $\beta$ at the blood-brain and blood-cerebrospinal fluid barriers. Proc. Natl. Acad. Sci. USA. 93:4229-4236.

39. Lucarelli, M., M. Gennarelli, R. Cardeli, G. Novelli, S. Scarpa, B. Dallapiccola, and R. Storm. 1997. Expression of receptors for native and chemically modified low-density lipoproteins in brain microvessels. FEBS Lett. 401:53-58.

40. Dehouck, B., L. Fenart, M.P. Dehouck, A. Pierce, G. Torpier, and R. Cecchelli. 1997. A new function for the LDL receptor: transcytosis of LDL across the blood-brain barrier. J. Cell Biol. 138:877-889.

41. Golden, P.L., T.J. Maccagnan, and W.M. Pardridge. 1997. Human blood-brain barrier leptin receptor: binding and endocytosis in isolated human brain microvessels. J. Clin. Invest. 99:14-18.

42. Goldstein, G.W., A.L. Betz, and P.D. Dowman. 1984. Use of isolated brain capillaries and cultured endothelial cells to study the blood-brain barrier. Fed. Proc. 43:191-195.

43. Ghersi-Egea, J.F., P.D. Gorevic, J. Ghiso, B.F. Frangione, C.S. Patlak, and J.D. Fenstermacher. 1996. Fate of cerebrospinal fluid-borne amyloid $\beta$-peptide: rapid clearance into blood and appreciable accumulation by cerebral arteries. J. Neurochem. 67:880-883.

44. Maness, L.M., W.A. Banks, M.B. Podlisny, D.J. Selkoe, and A.J. Kastin. 1994. Passage of human amyloid- $\beta$ protein 1-40 across the murine blood-brain barrier. Life Sci. 55:1643-1650.

45. Gajdusek, D.C. 1988. Transmissible and non-transmissible amyloidoses: autocatalytic post-translational conversion of host precursor proteins to $\beta$-pleated configurations. J. Neuroimmunol. 20:95-110.

46. Jarrett, J.T., and P.T. Lansbury, Jr. 1993. Seeding "one-dimensional crystallization" of amyloid: a pathogenic mechanism in Alzheimer's disease and scrapie? Cell. 73:1055-1058.

47. Soto, C., and B. Frangione. 1995. Two conformational states of amyloid $\beta$-peptide: implications for the pathogenesis of Alzheimer's disease. Neurosci. Lett. 186:115-118.

48. Thomas, T., G. Thomas, C. McLendon, T. Sutton, and M. Mullan. 1996. $\beta$-Amyloid-mediated vasoactivity and vascular endothelial damage. Nature. 380:168-171.

49. Thomas, T., E.T. Sutton, M.W. Bryant, and J.A.G. Rhodin. 1997. In vivo vascular damage, leukocyte activation and inflammatory response induced by $\beta$-amyloid. J. Submicrosc. Cytol. Pathol. 29:293-304.

50. Shayo, M., R.N. McLay, A.J. Kastin, and W.A. Banks. 1997. The putative blood-brain barrier transporter for the $\beta$-amyloid binding protein apolipoprotein J is saturated at physiological concentrations. Life Sci. 60:115-118.

51. Schmidt, A.M., M. Hasu, D. Popov, J.H. Zhang, J. Chen, S.D. Yan, J. Brett, R. Cao, K. Kuwabara, G. Gostache, et al. 1994. Receptor for advanced glycation end products (AGE) has a central role in vessel wall interactions and gene activation in response to circulating AGE proteins. Proc. Natl. Acad. Sci. USA. 91:8807-8811. 